\title{
The Usage of SEM for Fatigue Properties Evaluation of Austenitic Stainless Steel AISI 316L
}

Peter Palček, Monika Oravcová, Mária Chalupová, Milan Uhríčik

University of Žilina, Faculty of Mechanical Engineering, Department of Materials Engineering, Univerzitná 1, 01026 Žilina. E-mail: peter.palcek@fstroj.uniza.sk, monika.oravcova@fstroj.uniza.sk, maria.chalupova@fstroj.uniza.sk, milan.uhricik@fstroj.uniza.sk

Fatigue failure is a process resulting first from change of mechanical properties, then fatigue crack initiation occurs and progressive growth of crack (propagation of fatigue crack) leading to final fracture. The failure can occur either in low number of cycles $\left(\leq 10^{4}\right.$ cycles; low cycle fatigue) or over millions of cycles (high cycle fatigue). The fatigue behavior of AISI 316L austenitic stainless steel on microstructure was investigated. The fatigue fracture was investigated after three point cyclic bending test which was realized on V-notched testing bar. Fatigue crack nucleated from several sites under the notch. The failure mechanism proceeded afterwards by repeated episodes of fatigue striations as examined under scanning electron microscope. Before the fracture surface observation the surface hardness was measured under the originated crack where the area of plastic deformation can be found. In this area the hardness values raised approximately to $379 \mathrm{HV}$ due to plastic deformation strengthening. With the increasing distance from the crack the hardness values decreased approximately to $246 \mathrm{HV}$.

Keywords: Austenitic Stainless Steel, Fatigue Failure, Plastic Deformation, Three Point Cyclic Bending Test

\section{Acknowledgement}

This work has been supported by Scientific Grant Agency of Ministry of Education of Slovak republic VEGA 1/0683/15.

\section{References}

[1] SUDHAKAR, K. V. (2005). Metallurgical investigation of a failure in 316L stainless steel orthopaedic implant. Engineering Failure Analysis, Vol. 12, pp. 249-256.

[2] KANCHANOMAI, C., PHIPHOBMONGKOL, V., MUANJAN P. (2008). Fatigue failure of an orthopedic implant - A locking compression plate. Engineering Failure Analysis, Vol. 15, pp. 521-530.

[3] MIERZEJEWSKA, Ź. A., KUPTEL, P., SIDUN, J. (2016). Analysis of the surface condition of removed bone implants. Eksploatacja i Niezawodnosc - Maintenance and Reliability, Vol. 18, No. 1, pp. 65-72.

[4] TRIANTAFYlliDiS, G. K., KAZANTZIS, A. V., KARAGEORGIOU K. T. (2007). Premature fracture of a stainless steel 316L orthopaedic plate implant by alternative episodes of fatigue and cleavage decoherence. Engineering Failure Analysis, Vol. 14, pp. 1346-1350.

[5] AZEEZ, A. A. (2013). Fatigue failure and testing methods. Bachelor's thesis, pp. 32.

[6] STEVENSON, M. E., BARKEY, M. E., BRADT, R. C. (2002). Fatigue failures of austenitic stainless steel orthopedic fixation devices. ASM International, Vol. 2, No. 3, pp. 57-64.

[7] MIERZEJEWSKA, Ź. A. (2015). Case study and failure analysis of a total hip stem fracture. Advances in Materials Science, Vol. 15, No. 2, pp. 5-13.

[8] HUANG, H. M., TSAI, CH. M., CHANG, CH. CH., LIN, CH. T., LEE, S. Y. (2005). Evaluation of loading conditions on fatigue-failed implants by fracture surface analysis. The International Journal of Oral \& Maxillofacial Implants, Vol. 20, No. 6, pp. 854-859.

[9] R. M PILLIAR. (2009). Biomedical Materials. New York: Springer Science+Business Media, LLC. Vol. 23, pp. 41-81.

[10] N. THAPPA, M. PRAYSON, T. GOSWAMI. (2015). A failure study of a locking compression plate implant. Case Studies in Engineering Failure Analysis. Vol. 3, pp. 68-72.

[11] ZÁVODSKÁ, D., GUAGLIANO, M., BOKU゚VKA, O., TRŠKO, L. (2016). Effect of Shot Peening on the Fatigue Properties of 40NiCrMo7 steel. Manufacturing Technology, Vol. 16, No. 1, pp. 295-299.

[12] STUDENÝ, Z. (2015). Analysis of the Influence of Initiating Inclusions on Fatigue Life of Plasma Nitrided Steels. Manufacturing Technology, Vol. 15, No. 1, pp. 99-105.

Paper number: M2016206

Copyright (C) 2016. Published by Manufacturing Technology. All rights reserved. 